\title{
GLOTTODYDAKTYCZNE ASPEKTY OPISU SŁOWNIKOWEGO KOLOKACJI
}

\section{WPROWADZENIE}

Dostępne na rynku słowniki przekładowe z językiem polskim i rosyjskim we współczesnej dydaktyce języka rosyjskiego wydają się raczej rzadką pomocą w nauczaniu języka rosyjskiego jako obcego. I nie dzieje się tak bez przyczyny, w odniesieniu bowiem do ich zawartości niejednokrotnie można przywołać słowa Tadeusza Piotrowskiego, że „słownik nie jest użyteczny nawet przy rozumieniu czytanego tekstu" (Piotrowski 50), nie wspominając już o tworzeniu tekstu nowego.

Dylemat leksykografia dydaktyczna - leksykografia ogólna zdaje się jednak w ostatnich dziesięcioleciach coraz bardziej rozmywać. Dzieje się tak przede wszystkim za sprawą orientacji na użytkownika słownika, przynajmniej w szeroko pojętej metaleksykografii ${ }^{1}$, choć niekoniecznie leksykografii praktycznej. Docenia się coraz bardziej wagę złożonej natury jednostek leksykalnych, w tym ich syntagmatyczności, a co za tym idzie - znaczenie kompetencji kolokacyjnej jako składowej kompetencji leksykalnej (por. Targońska 110).

Niniejszy artykuł jest pewnym rozszerzeniem tematyki podejmowanej przez nas w publikacji „Myśl - słowo - użycie, czyli o strukturze semantycznej artykułu hasłowego w słowniku przekładowym polsko-rosyjskim na przykładzie polskiego leksemu przeżyć oraz jego rosyjskich odpowiedników” (Labocha 283-292)2. O ile w tamtym tekście zasadniczym celem

Dr Maciej Labocha - Uniwersytet Śląski w Katowicach, Instytut Językoznawstwa; e-mail: maciej.1abocha@us.edu.pl; ORCID: https://orcid.org/0000-0002-8763-2187.

${ }^{1}$ Zob. w szczególności publikacje konferencji Euralex (euralex.org/).

${ }^{2}$ W tym tekście terminy „słownik przekładowy” oraz „słownik dwujęzyczny” będą stosowane zamiennie. 
było odpowiednie zsekwencjonowanie znaczeń triady leksemów przeżyć прожить - пережить, to przedmiotem niniejszych rozważań jest glottodydaktyczne spojrzenie na kolokacje zawarte w przedstawionym we wspomnianej publikacji modelu artykułu hasłowego dla słownika przekładowego polsko-rosyjskiego typu ogólnego.

Artykuł składa się z następujących części: Wprowadzenie; 1. Potrzeby użytkownika a typy słowników (dydaktyczny vs. ogólny); 2. Jednostki wielowyrazowe w słowniku przekładowym; 3. Analiza korpusowa a modelowanie artykułu hasłowego; Podsumowanie. Części 1. i 2. mają charakter teoretyczny, natomiast część 3. stanowi w głównej mierze analizę korpusową kolokacji ze względu na ustalony podział znaczeń. Celem jest poświadczenie korpusowe łączliwości, określenie schematów łączliwości, a w rezultacie modyfikacja modelowego artykułu hasłowego w taki sposób, aby ułatwiał on potencjalnie intuicyjny proces akwizycji reguł łączliwościowych.

\section{POTRZEBY UŻYTKOWNIKA A TYPY SŁOWNIKÓW (DYDAKTYCZNY VS. OGÓLNY)}

Ponieważ słowniki nie powinny być projektowane w oderwaniu od potrzeb użytkownika (ros. пользовательские запросы, ang. user's needs), w literaturze metaleksykograficznej przyjmuje się zwykle pewne założenia, mające na celu zaspokojenie tychże potrzeb. Jeśli porównamy takie założenia np. wobec słownika dydaktyczno-kombinatorycznego oraz słownika dwujęzycznego ogólnego u badaczy, zauważymy, że bywają one zbieżne. M.V. Vlavatskaya, opisując, czym powinien być dydaktyczny słownik kombinatoryczny angielsko-rosyjski, stwierdza:

Англо-русский учебный комбинаторный словарь, по нашему мнению, должен стать эффективным средством овладения английским языком. Непременным условием его активного использования является умение правильно употреблять и сочетать слова для выражения определённых речевых заданий и осуществлять их успешную реализацию в речевых контекстах. Создавая неординарную лексикографическую концепцию, необходимо иметь в виду, что осознание преподавателями и лексикографами роли родного языка в изучении иностранного способствовало возникновению новой тенденции в построении одноязычных учебных словарей, а точнее, их билингвилизации. (Vlavatskaya 33) 
Dla projektowanego słownika Vlavatskaya przyjmuje więc założenie o jego efektywności w produktywnym sensie, ze szczególnym uwzględnieniem łączliwości wyrazów w kontekstach. Realizacji tego założenia ma służyć bilingwizacja słownika, realizowana poprzez podawanie ekwiwalentów w języku użytkownika słownika. Co więcej, o projektowanym słowniku Vlavatskaya pisze:

(...) предлагаемый англо-русский учебный комбинаторный словарь - это не традиционный словарь, а новый тип словаря, назначение которого - помогать изучающим английский язык использовать слова, которые они уже знают, более эффективно. Прежде всего это касается заголовочных слов, которые относятся к наиболее употребительной лексике, т.е. обладают высокой частотностью. Цель англо-русского учебного комбинаторного словаря способствовать развитию речи учащихся на английском языке. (34)

Założenie o produktywnej efektywności jest więc uzupełnione o postulat rozwoju umiejętności językowych uczniów czy studentów. Tymczasem niemal trzy dekady wcześniej Sue Atkins w odniesieniu do słowników dwujęzycznych w kontekście potrzeb użytkownika zauważa, że słowniki takie powinny służyć:

(1) rozumieniu języka docelowego (pisanego i mówionego),

(2) tłumaczeniu z i na język docelowy,

(3) umiejętności wyrażania się w języku docelowym (w mowie i piśmie),

(4) uzupełnianiu wiedzy o języku docelowym, a także

(5) uzupełnianiu wiedzy o ekwiwalencji oraz różnicach między jednostkami dwóch języków (Atkins 526).

Podział na słowniki dydaktyczne i ogólne w kontekście powyższych wypowiedzi badaczek traci więc swoją wyrazistość. Oczywiście faktyczna realizacja poszczególnych wydawnictw na poziomie makro- i mikrostruktury może przybierać rozliczne formy, granice jednak na poziomie głównie mikrostruktury i jej celów teoretycznie zacierają się.

Co do słowników dwujęzycznych Atkins sformułowała zresztą więcej postulatów. Jednym z ważniejszych wydaje się postulat, że wszelkie metainformacje powinny być - w odróżnieniu od projektu słownika dydaktycznego Vlavatskiej - zapisywane w języku użytkownika, że powinny być one transparentne.

W tym jednak przypadku podkreślana jest również waga połączeń wyrazowych i kontekstów. W zasadzie można powiedzieć, że kolokacje są tym elementem opisu jednostki leksykalnej, która pozwala wydobyć ramy jej znaczenia i użycia, natomiast definicje (semantyzacja) stanowią koncep- 
tualne/kognitywne uzupełnienie wiedzy o znaczeniu poszczególnych jednostek, pewną nadrzędną regułę. Wagę przyswajania odpowiednio dobranych przykładów ponad uczenie się reguł (np. definicji) dobrze ilustrują słowa Manfreda Spitzera:

Badania z użyciem sieci neuronowych pokazały, że symulowane komórki nerwowe, po właściwym treningu $\mathrm{z}$ odpowiednimi przykładami, generują prawie każdą zasadę, tzn. potrafią ją zastosować, umieją ją. (...) Nasz język (...) [z]awiera mnóstwo zasad, o których nie wiemy, ale które umiemy. Te ogólne zasady mamy w głowie nie $\mathrm{w}$ formie reguł (które potrafilibyśmy zapisać), ale $\mathrm{w}$ formie umiejętności, jaką jest opanowanie naszego języka ojczystego. Patrząc na to przez pryzmat uczenia się w szkole czy na uniwersytecie, widzimy, że nie może chodzić o bezmyślne uczenie się regułek na pamięć. To, czego potrzebują dzieci, to przykłady. Bardzo dużo przykładów, w miarę możliwości poprawnych i dobrych. Reguły wymyślą się wtedy same. $(63,68)$

Zapewnienie dobrego i czytelnego opisu słownikowego poszczególnych jednostek leksykalnych, nieobciążającego systemu poznawczego, może wspomóc akwizycję języka na poziomie intuicyjnym, a więc poziomie pomiędzy zachowaniami automatycznymi a zachowaniami kontrolowanymi. Kontakt ze słownikiem, który jest oparty na czytelnej i przemyślanej mikrostrukturze, jest bowiem rodzajem ekspozycji użytkownika na formy językowe opisane w sposób pozwalający na mniej lub bardziej świadome uchwycenie reguł np. semantyczno-syntagmatycznych (por. Piegzik 150). Opis chaotyczny - jak można sądzić - będzie uchwycenie takich reguł utrudniać.

\section{JEDNOSTKI WIELOWYRAZOWE W SŁOWNIKU PRZEKŁADOWYM}

Jednostki wielowyrazowe mogą w słowniku posiadać co najmniej dwojaki status: jednostki indeksowej lub ilustracji semantyczno-syntagmatycznej jednostki indeksowej. W pierwszym przypadku status jednostki indeksowej posiadają co do zasady te wielowyrazowce, które cechuje sens globalny, a dokładniej rzecz ujmując - jednostki, które można zdefiniować jako „ciąg niepodzielny semantycznie na takie podciągi znaczące, które byłyby elementami klas substytucyjnych niezamkniętych" (Grochowski 28; por. Przybylska et al. 18-19). Ilustrację dla znaczeń poszczególnych polisemów będą zatem stanowić przede wszystkim związki wyrazowe, które można rozpatrywać w kontekście łączliwości systemowej (kategorialnej) lub łączliwości norma- 
tywnej, a więc te, które sensu globalnego nie posiadają, ale również nie stanowią połączeń jednostkowych (choć bywają od tej reguły wyjątki). Różnicę między nimi doskonale opisuje (ilustruje) Teresa Rokicka:

Za systemowe uznamy te schematy łączliwości leksykalnej, w których obok wyrazu-centrum można wpisać nie konkretną jednostkę słownikową, lecz abstrakcyjną klasę semantyczną, które ta jednostka współtworzy, np. rozległy + nazwy przestrzeni otwartych czy doznać o podstawowym znaczeniu 'odczuć, poczuć, doświadczyć, przeżyć', który wykazuje dwustronne ograniczenie łączliwości: w pozycji podmiotu musi wystąpić nazwa istoty czującej (..), w pozycji dopełnienia zaś - nazwy wyrażeń psychicznych. Łączliwość leksykalna (...) może mieć różny zasięg - od łączliwości absolutnej (...) aż po łączliwość minimalną (...) klasę jednoelementową, np. (...) fedrować - tylko węgiel. Do sfery łączliwości normatywnej zaliczamy te schematy, w których niemożliwe jest określenie kategorii semantycznej wyrazów łączących się z wyrazem-centrum. Jej zakres wyznaczamy poprzez wyliczenie elementów, które mogą z nim tworzyć poprawne związki; wyraz bowiem nie wykorzystuje wszystkich możliwych połączeń, wynikających z jego semantyki (...) Nie zawsze możliwe jest dokładne rozgraniczenie łączliwości systemowej i kategorialnej. (79-80)

Można zakładać, że w sensie produktywnym dla użytkownika kolokacje (przypadki łączliwości) potwierdzają regułę zawartą w definiensie (równoważnym wobec jednostki definiowanej wyrażeniu, a więc definicji słownikowej czy formule o zbieżnym charakterze), a definiens potwierdza charakter kolokacji, co stanowi pewien dwustopniowy system weryfikowalności zastosowania jednostki w tekście i kontekście.

Oczywiście można również dyskutować zakres podawanej informacji kolokacyjnej - z jednej strony, jak już zostało powiedziane, jest istotne, by słownik zawierał tak wiele przykładów, jak to tylko możliwe, z drugiejwciąż mamy do czynienia $\mathrm{z}$ problemem zakresu podawanej informacji, m.in. o kolokacjach właśnie. Pewnego rodzaju złotą regułę podaje Mirosław Bańko, a sprowadza się ona do pojęcia tzw. elegancji:

Podobnie jak w fizyce czy matematyce za eleganckie uznaje się takie rozwiązanie problemu, które jest jednocześnie skuteczne i proste, tak też w leksykografii elegancja wymaga uzgodnienia sprzecznych dążeń: z jednej strony opis leksykograficzny powinien być wyczerpujący i dokładny (w stopniu adekwatnym do potrzeb i oczekiwań odbiorcy), z drugiej zaś powinien być zwięzły i prosty. (...) Słowniki przeznaczone dla ludzi - w przeciwieństwie do tych, które sporządza się z myślą wyłącznie o zastosowaniach maszynowych - muszą bowiem brać pod uwagę ludzką percepcję informacji, w tym przyjemność estetyczną i intelektualną wynikającą ze spostrzeżenia, że opis czegoś, co wydawało się trudne, jest jednocześnie trafny i zaskakująco prosty. (10-11) 
W związku z tym kwestią niejako otwartą pozostaje ustalenie efektywnej liczby kolokacji pozwalających - wraz z odpowiednią semantyzacją na uświadomienie (odgadnięcie) i zakodowanie reguły i jej praktyczne zastosowanie w produkcji tekstu pisanego i mówionego. Jest to jednak temat na odrębne studium.

\section{ANALIZA KORPUSOWA \\ A MODELOWANIE ARTYKUŁU HASŁOWEGO}

We wspomnianym artykule „Myśl - słowo - użycie...”, opierając się na definicjach słowników jednojęzycznych, zaproponowaliśmy nową, bardziej szczegółową filiację dla znaczeń nieprzenośnych wraz z pojedynczymi ekwiwalentami (Labocha 286-287, 291). Ustaliliśmy następującą sekwencję znaczeń, przekładającą się na większą czytelność oraz mniejsze ryzyko błędów (Tab. 1):

Tab. 1.

\section{ZESTAW ZNACZEŃ NIEPRZENOŚNYCH I EKWIWALENTÓW LEKSEMU PRZEŻYĆ}

1. żyjąc, przebyć, przetrwać jakiś czas

прожить

2. przetrzymać jakieś wydarzenia, wypadki, nie stracić życia

пережить

3. zostać przy życiu dłużej od kogoś lub czegoś

пережить

4. spędzić [żyjąc] jakiś czas w jakimś miejscu

прожить

5. spędzić [żyjąc] jakiś czas w relacji z kimś

прожить

6. pot. poradzić sobie w codziennym życiu, mając do dyspozycji minimalne środki materialne

прожить

Przy tworzeniu modelowego artykułu hasłowego dla słownika przekładowego typu ogólnego posłużyliśmy się pojedynczymi przykładami kolokacji zaczerpniętymi z tekstów korpusowych i internetowych. Przykłady te zostały ograniczone do pojedynczych kolokacji, mających najlepiej ilustrować znaczenie i ściśle korelować z zaproponowanymi definicjami, stanowiącymi semantyzację jednostki polskiej:

\section{[przeżyćc]}

1. (żyjąc, przebyć, przetrwać jakiś czas) прожить сколько лет и т.д. / как долго;

$\sim 82$ lata прожить 82 года 2. (przetrzymać jakieś wydarzenia, wypadki, nie stracić życia) пережить что; wojnę пережить войну 3. (zostać przy życiu dlużej od kogoś lub czegoś) пережить кого, что; swoje dzieci пережить своих детей 4. (spędzić [żyjąc] jakiś czas w jakimś miejscu) прожйьь где; 〜 
w Warszawie 45 lat прожить в Варшаве 45 лет 5. (spędzić [żyjąc] jakiś czas w relacji z kimś) прожить (вместе) с кем; wspólnie 30 lat прожить вместе 30 лет 6. (poradzić sobie $w$ codziennym życiu, mając do dyspozycji minimalne środki materialne) прожить на что; za minimalne wynagrodzenie прожйть на прожиточный минимум

Zastosowana metoda wiodła więc od znaczeń ujętych w słownikach jednojęzycznych do wystąpień tekstowych. Metoda odwrotna pozwala natomiast na weryfikację znaczeń oraz uzupełnienie zestawów kolokacji. We wcześniejszym badaniu nie analizowano jednak szeregów kolokacyjnych, ani nie weryfikowano schematów semantyczno-leksykalnych łączliwości.

Poniżej, by uzupełnić tę lukę, przedstawiamy wyniki poświadczeń tekstowych według zasobów Narodowego Korpusu Języka Rosyjskiego, wskazujące zasięg i schematy kolokacji. Są to - rzecz jasna - również wybrane wystąpienia tekstowe, pełna bowiem analiza zasobów wymagałaby znacznie szerszego opisu. Jednostkami, dla których poszukiwano korpusowych poświadczeń łączliwości, były czasowniki прожить oraz пережить w formie bezokolicznika, formach osobowych oraz formach czasu przeszłego. Nie były podstawą wyszukiwania zastane w słownikach lub domniemane przypadki połączeń wyżej wymienionych jednostek z jakimikolwiek kolokantami. Jednostki były wyszukiwane bez nadawania jakichkolwiek ram genologicznych czy czasowych. Założenia takie miały na celu zobiektywizowanie rezultatów.

Znaczenie pierwsze ('żyjac, przebyć, przetrwać jakiś czas') określają następujące poświadczenia korpusowe (Tab. 2.):

Tab. 2.

Lp.

PoŚWIAdCZENIE KORPUSOWE (www.ruscorpora.ru)

Znaczenie (№)

1. Но чтобы понять все это - и неожиданное «против», и почему, - надо прожить долгую жизнь, и часто все равно не поймешь.

2. Отношения в их семье всегда были бурными - без слёз, ругани и страстных поцелуев не могли они прожить ни дня.

3. Александр Ефимович мне сказал, антр ну, как говорится, что с таким сердцем, как у Геннадия, можно прожить сто лет.

4. Я больше не в силах! Я больше не проживу одного месяца! месяца! Мне лучше - умереть!

5. Половина из них не стоит на учете, не получает лечения, а значит, проживет не более 15 лет (средний срок жизни ВИЧ-инфицированных без получения ретроантивирусной терапии - 10-12 лет).

6. Скорее всего, нынешний год проживем, как и минувший, - в вялотекущем режиме. 
Wyłaniający się z nich schemat semantyczno-leksykalny łączliwości jest następujący: прожить + 'czas (określony lub nieokreślony)', natomiast szereg kolokacyjny można dla jasności interpretacyjnej uporządkować na pewnej skali, począwszy od wartości 'czas nieokreślony', a na najmniejszej jednostce 'czasu określonego' kończąc (lub odwrotnie), a mianowicie: прожить жизнь / несколько лет / год / месяц / день еtс.

Znaczenie drugie ('przetrzymać jakieś wydarzenia, wypadki, nie stracić życia') określają poświadczenia (Tab. 3):

Tab. 3.

Lp.

POŚWIAdCZENIE KORPUSOWE (www.ruscorpora.ru)

Znaczenie (№)

7. Генералу также надо будет организовать строительство палаточных городков, чтобы беженцы могли пережить зиму, тушить пожары, охранять школы и обеспечивать жителей водой и пищей.

8. Более тридцати лет прослужил Курлов трем российским императорам, пострадал по делу 06 убийстве Столыпина, пережил Февральскую революцию и отречение Николая II от престола, был арестован Временным правительством, после победы большевиков бежал за границу (...)

9. Когда Дмитриев познакомился с ним, Иван Васильевич был уже сильно стар, грузен, страдал одышкой, пережил инфаркт, всяческие невзгоды и бури вроде снятия с работы, партийных взысканий, восстановлений, назначений с повышением, клевет (...)

10. Японец Араки Ясусада якобы пережил бомбардировку Хиросимы и написал 14 записных книжек - автор этой мистификации неизвестен до сих пор, а среди подозреваемых есть даже Андрей Битов и Д. А. Пригов.

11. Андрей Павлович пережил в детстве тяжелое воспаление лёгких, что сильно сказалось на его дыхании.

12. Мы живем в мире, где каждый десятый или воевал, или пострадал в катастрофе, или пережил пожар, или стал жертвой преступления.

13. Увы, но, выжив в Тунгусском взрыве, он не пережил обычных уличных беспорядков и погиб в Алжире в возрасте 42 лет.

14. Брук пережил три инсульта за последние десять лет своего правления.

Nadrzędny schemat łączliwości semantyczno-leksykalnej jest w tym wypadku następujący: пережить + 'wydarzenie zagrażające życiu', można go jednak podzielić na co najmniej cztery warianty: (1) пережить + 'nazwa wydarzenia o charakterze konfliktu zbrojnego lub wydarzeń z niego wynikających', (2) пережить + 'nazwa zdarzenia o charakterze nieszczęśliwego wypadku, zdarzenia losowego lub klęski żywiołowej’, (3) пережить 
+ 'nazwa długotrwałych zjawisk klimatycznych nie sprzyjających podtrzymaniu życia', (4) пережить + 'nazwa zdarzenia o charakterze medycznym'. Dzięki temu możliwe jest uporządkowanie poszczególnych kolokacji i ich szeregów: (1) пережить революцию / бомбардировку / уличные беспорядки, (2) пережить пожар, (3) пережить зиму, (4) пережить инфаркт / инсульт / воспаление лёгких еtс.

Znaczenie trzecie ('zostać przy życiu dtużej od kogoś lub czegoś') w przypadku wstępnych poszukiwań w Narodowym Korpusie Języka Rosyjskiego wyłącznie dla słowa kluczowego nережumb oraz jego poszczególnych form paradygmatycznych określają następujące poświadczenia (Tab. 4):

Tab. 4.

Lp.

15. Абрамович не только благополучно пережил Ельцина, но при Путине заметно расширил свою империю, придав ей алюминиевый блеск.

16. Юрий Владимирович пережил Анатолия Андреевича месяца на два.

17. Прасковью, которая жаловалась, что всех пережила и перехоронила, а её вот смертушка не берёт, ещё рассказывала, как рыла осенью сорок первого окопы под Москвой...

Są to jednak poświadczenia, które wydają się mało efektywne w sensie egzemplifikacyjnym czy poglądowym, ponieważ prezentują regułę, nie odwołując się do najbardziej obrazowych i wyrazistych konotacji. Za takie moglibyśmy zaś przede wszystkim uznać te, które opierają się na znaczeniu 'żyć dtużej niż ktoś, kto (co do zasady) powinien żyć dtużej'. Przetrwanie dtużej niż coś jest natomiast wynikiem bezpośredniego przeniesienia wyżej wspomnianego znaczenia na różnego rodzaju obiekty. W takim przypadku dodatkowa weryfikacja korpusowa schematu łączliwości semantyczno-leksykalnej пережить + 'nazwa osoby' wydaje się wskazana. W związku $\mathrm{z}$ ustalonym schematem łączliwości kolokacjami podejrzewanymi o większy stopień regularności są пережить мужа / жену / детей / сына / дочь, które stanowią szereg pozwalający na łatwe odczytanie reguły łączliwości opartej na kontraście wiekowym (zakładanej przeżywalności) - potwierdzają je wystąpienia korpusowe (Tab. 5): 
Tab. 5

Lp.

18. Там он простудился и умер. А Зоя Петровна, жена его, пережила мужа почти на шестьдесят лет.

19. Действительно. Степан Иванович пережил жену, которая умерла в середине восьмидесятых, он давно вышел на пенсию.

20. - «Все равно, - ответил убивавший, - мне довольно знать, что мои дети хоть ненадолго переживут детей Агафокла».

21. Мать намного пережила сына, я видел ее в Ленинграде на похоронах Александра Ивановича уже глубокой старухой.

22. Тамара написала ему об этом, в письме была фотография. Мать ненадолго пережила дочь. И вот недавно Лев увидел на обочине дороги копию своей дочки.

Znaczenie czwarte ('spędzić [̇̇yjąc] jakiś czas w jakimś miejscu') jest pochodną i rozszerzeniem zarazem znaczenia pierwszego ('żyjace, przebyć, przetrwać jakiś czas'). Jest ono o tyle ważne, że w języku rosyjskim mamy przecież do wyboru dwa ekwiwalenty przekładowe (прожить oraz neрежить), ów więc wariant znaczeniowy (pociągający za sobą odpowiednie kolokacje), jak sądzimy, powinien zostać uwzględniony jako odrębny element filiacji słownika przekładowego. Znaczenie to określają i ilustrują następujące poświadczenia korpusowe (Tab. 6):

Tab. 6.

Lp.

23. После всех Ваших высказываний я изменила к Вам отношение. Прожить 21 год в Германии и так отзываться об этой стране. Это недостойно уважения.

24. Я могу Вам сообщить следующее: из моих 21 года постоянного проживания в Германии я прожил 14 лет в Баварии, в Нюрнберге.

25. Ровно пол жизни прожил во Франции, но то и дело сравнивал с Россией единственной точкой отсчёта.

26. Я прожил в Москве полтора года, и это была моя стажировка в МИДе, потом, когда я сдал экзамен в Бонне, меня направили в Токио.

27. Двадцать лет он прожил в Париже, работал бухгалтером в банке.

28. Я всю жизнь прожил в Ленинграде и привык чувствовать рядом море. 
29. И хотя медицинская сестра Терентьева всю жизнь прожила в городе, она, опустившись на колени, тихонько, чтобы не тревожить живых, завыла подеревенски: - Родименький наш, цветочек ты наш, куда ты ушёл от нас?

30. - Вы всю жизнь прожили в провинции. А другим писателям советовали жить в столице, называя это необходимым благом.

Zasadniczy schemat łączliwości semantyczno-leksykalnej wynikający z wyżej wymienionych poświadczeń jest następujący: прожить + в + 'toponim' + 'czas określony lub nieokreślony'. Szereg kolokacyjny wydaje się oczywisty, dobrze jednak, by uwzględniał wszystkie warianty wynikające ze schematu łączliwości (typy toponimów oraz sposób określania czasu), a więc: прожить в Германии 21 год, прожить во Франции полжизни, прожить в Париже двадцать лет, прожить всю жизнь в городе / в провинции. Uporządkowanie w tym przypadku można skoncentrować na rodzaju toponimu lub sposobie określania czasu.

Podobnie do znaczenia poprzedniego ('spędzić [żyjąc] jakiś czas w jakimś miejscu') również znaczenie piąte ('spędzić [żyjąc] jakiś czas $w$ relacji z kims') silnie skorelowane jest ze znaczeniem prymarnym (pierwszym). Również i w tym przypadku należy jednak pamiętać, że użytkownik ma do wyboru dwa ekwiwalenty rosyjskie. Znaczenie piąte określają i ilustrują następujące wystąpienia tekstowe (Tab. 7):

Tab. 7.

Lp.

31. Если людям удалось прожить вместе 10 лет - это уже здорово. 10 лет большой стаж. Много хорошего может произойти с людьми за 10 лет.

32. Я думал, что, когда мы кончим школу, я женюсь на этой девочке, мы проживем вместе всю жизнь, но она неожиданно куда-то уехала со своими интеллигентными родителями, на новое место жительства.

33. Особенно этот спектакль будет интересен тем, кто прожил в браке не один год.

34. Понимая, что несчастная женщина не в состоянии теперь расстаться с его дочерью, он, человек с университетским образованием, полученным в Лондоне, женился на ней, и они прожили вместе тридцать лет.

35. С выбранной мне отцом женой мы прожили одиннадцать лет.

36. Мы прожили с Иолантой одиннадцать лет. У нас прекрасная взрослая дочь и замечательные внуки. 
37. Что это значит? Вы прожили вместе четверть века! В чем причина?» И тот ему отвечает: «Извините, ребе, но, пока она моя жена, я ничего плохого говорить не намерен».

38. Мы с отцом прожили сорок лет, ни одного грубого слова не сказали друг другу. Живите дружно, любите друг друга.

W przypadku leksemu прожить we wskazanym znaczeniu możemy wydzielić trzy schematy łączliwości semantyczno-leksykalnej: (1) прожить + вместе + 'czas (określony lub nieokreślony)', (2) прожить $+\mathrm{c}+$ nazwa osobowa w N. + 'czas (określony lub nieokreślony)', (3) прожить + в + nazwa relacji w. Msc. + 'czas (określony lub nieokreślony)'. Szeregi kolokacyjne można podzielić zatem następująco (odpowiednio do powyższych schematów): (1) прожить вместе всю жизнь / четверть века / тридцать лет / 10 лет, (2) прожить с отцом сорок лет / с женой одиннадцать лет / с Иолантой одиннадцать лет, (3) прожить в браке не один год.

Ostatnie ze znaczeń niemetaforycznych, szóste, skoncentrowane nie na 'przeżyciu jakiegoś czasu', tj. 'trwaniu', ale na 'przetrwaniu - bez utraty życia - jakiegoś czasu', a mianowicie oznaczające potocznie 'poradzić sobie w codziennym życiu, mając do dyspozycji minimalne środki materialne' delimitują i ilustrują następujące przykłady wystąpień tekstowych (Tab. 8.):

Tab. 8.

Lp.

PośWIAdCZENIE KORPUSOWE (www.ruscorpora.ru)

Znaczenie (№)

39. Литературный фонд присылал гроши. На литературные заработки мало кто из писателей эмиграции мог прожить.

40. Я одинок, и мне трудно прожить только на маленькую пенсию, много денег уходит на лекарства.

41. Раньше считалось, что в России средний человек может прожить на 1137 руб. в месяц. Новый прожиточный минимум выглядит несколько сомнительно.

42. Ну да, муж... На одну зарплату разве сейчас проживёшь...

43. Никто же не поможет, только все время давят на психику со всех сторон! Ты не проживешь ни на какое пособие, это вообще все совершенно невыносимо.

44. Жизнь же студента - нищенская («Носим ношеное, а употребляем брошенное», - говорили они тогда), на стипендию в 25 рублей не проживешь.

45. Прошла трудовой путь от простой рабочей до руководителя; Я трудилась, всю жизнь отдала заводу, а на пенсию не проживешь; (...) 
46. - Извини, на твою зарплату не проживешь, поэтому я и набрала учеников, у меня-то нет оклада, что натопаешь, то и полопаешь, к трем ученикам пойдешь - четыреста пятьдесят рубликов получишь, к четырем - шестьсот!

47. Им даже нашли скромные рабочие места, где можно подработать. На студенческую стипендию, понятное дело, не проживешь.

48. На зарплату медсестры не проживешь, разве что любовник богатый, но на это что-то не похоже.

Podobnie do łączliwości w przypadku znaczenia 2. i tutaj możemy wyróżnić schemat nadrzędny (jednak z odmiennym członem głównym): прожить + на + 'określona lub nieokreślona kwota pieniężna / nazwa świadczenia pieniężnego' w formie B. Możemy i w danej grupie zapisać przykłady połączeń wyrazowych wg. pewnej reguły - od kwot określonych i nieokreślonych po nazwy świadczeń (lub odwrotnie bądź w konfiguracji mieszanej): прожить на 1137 руб., прожить на стипендию в 25 рублей, прожить на литературные заработки, прожить на одну зарплату, прожить на пенсию, прожить на пособие.

W każdym z analizowanych przypadków schemat semantyczno-leksykalny jest składniowo/walencyjnie wariantywny. W przytoczonych przykładach wariantywności tej nie ujęliśmy ze względu na czytelność formy, ale także ze względu na zunifikowanie zapisu do celów leksykograficznych. Wydaje się, że wariantywność składniową/walencyjną użytkownik będzie w stanie stosować intuicyjnie. Słuszność takiego poglądu należałoby oczywiście potwierdzić odrębnym badaniem, np. przekładowym.

Podsumowując ustalone szeregi kolokacyjne, przedstawmy je zbiorczo bez semantyzacji (Tab. 9):

Tab. 9.

\begin{tabular}{|c|c|c|c|}
\hline ZNACZENIE (№) & JEDNOSTKA WEJŚCIOWA & JEDNOSTKA WYJŚCIOWA & KOLOKAJJE \\
\hline 1 & przė̇yć & прожить & $\begin{array}{l}\text { прожить жизнь / несколько лет / год / } \\
\text { месяц / день }\end{array}$ \\
\hline 2 & przeżyć & пережить & $\begin{array}{l}\text { пережить революцию / бомбардировку } \\
\text { / уличные беспорядки, } \\
\text { пережить пожар, } \\
\text { пережить зиму, } \\
\text { пережить инфаркт / инсульт / } \\
\text { воспаление лёгких }\end{array}$ \\
\hline 3 & przeżyć & пережить & $\begin{array}{l}\text { пережить мужа / жену / детей / сына / } \\
\text { дочь }\end{array}$ \\
\hline
\end{tabular}


4

przeżyć

przeżyć

5

6 прожить

прожить

прожить прожить в Германии 21 год / во Франции пол жизни / в Париже двадиать лет / всю жизнь в городе (в провинции)

прожить вместе всю жизнь / четверть века / тридцать лет / 10 лет,

прожить с отцом сорок лет / с женой одиннадцать лет / с Иолантой одиннадиать лет, прожить в браке не один год

прожить на 1137 руб. / на стипендию в 25 рублей / на литературные заработки / на одну зарплату / на пенсию / на пособие

Wydaje się jasne, że z samego zestawu kolokacji użytkownik może intuicyjnie wysnuć reguły, o których pisze Spitzer, istotne jednak, by był to zestaw - by jeszcze raz posłużyć się słowami badacza - „w miarę możliwości poprawny i dobry".

Zebrany materiał warto porównać $\mathrm{z}$ materiałem zamieszczonym $\mathrm{w}$ trzech wielkich słownikach przekładowych polsko-rosyjskich - Wielkim słowniku polsko-rosyjskim Wiedzy Powszechnej pod red. Dymitra Hessena i Ryszarda Stypuły (WSPR WP), Wielkim słowniku polsko-rosyjskim [i] rosyjsko-polskim pod. red. Sergiusza Chwatowa i Mikołaja Timoszuka (WSPR[i]RP REA), a także w elektronicznym Wielkim stowniku polsko-rosyjskim PWN (WSPRiRP PWN), opracowanym na podstawie słowników pod. red. Jana Wawrzyńczyka (Tab. 10):

Tab. 10.

\section{KOLOKACJE ZASTOSOWANE W ARTYKUŁACH HASŁOWYCH DLA LEKSEMU PRZEŻYĆ W WIELKICH SŁOWNIKACH POLSKO-ROSYJSKICH / ROSYJSKO-POLSKICH}

WSPR WP

WSPR[i]RP REA

прожить сто лет

прожить до конца месяца

пережить драму

пережить кого-л. на несколько

больной не переживёт этой ночи лет

отец пережил сына

пережить кризис

пережить большую радость

POZA FILIACJĄ ( PO ZNAKU

ROMBU):

przeżyć w pamięci

сохраниться в памяти

przeżyć samego siebie

пережить (самого) себя
POZA FILIACJĄ (PO ZNAKU

ROMBU):

przeżyć życie

отжить

przeżyty (przestarzały)

отживший

WSPRIRP PWN 
Nietrudno zauważyć, jak bardzo potencjał kolokacyjny (przekładowy, stylistyczny, dydaktyczny) poszczególnych jednostek leksykalnych bywa w słownikach dwujęzycznych niedoceniany.

Ponieważ celem niniejszego artykułu jest również zaproponowanie zmodyfikowanej wersji modelowego artykułu hasłowego dla leksemu przeżyć, poniżej przedstawiamy taką próbę (zmieniony dla większej czytelności został także system wyróżnień graficznych poszczególnych translatów i kolokacji):

PRZEŻYĆ 1. (żyjąc, przebyć, przetrwać jakiś czas) ПРОжить сколько лет и т.д. / как долго; życie / kilka lat / rok / miesiąc / dzień прожить жизнь / несколько лет / год / месяц / день 2. (przetrzymać jakieś wydarzenia, wypadki, nie stracić żсіа) ПЕРЕжить что; rewolucję / bombardowanie / zamieszki пережить революцию / бомбардировку / уличные беспорядки; pożar пережить пожар; zimę пережить зиму; zawal / udar / zapalenie płuc пережить инфаркт / инсульт / воспаление лёгких 3. (zostać przy życiu dłużej od kogoś lub czegoś) ПЕРЕЖИть кого, что; męża / żonę / dzieci / syna / córkę пережить мужа / жену / детей / сына / дочь 4. (spędzić [żyjac] jakiś czas w jakimśs miejscu) Прожить где; w Niemczech 21 lat / pół życia we Francji / 20 lat w Paryżu / cale życie w mieście (na prowincji) прожить в Германии 21 год / во Франции полжизни / в Париже 20 лет / всю жизнь в городе (в провинции) 5. (spędzić [żyjac] jakiś czas w relacji z kimś) Прожить (вместе) с кем; wspólnie cale życie / ćwierć wieku / 30 lat прожить вместе всю жизнь / четверть века / 30 лет; z ojcem 40 lat / z żoną 11 lat / z Jolantą 11 lat прожить с отцом 40 лет / с женой 11 лет / с Иолантой 11 лет; w malżeństwie nie jeden rok прожить в браке не один год 6. (poradzić sobie w codziennym życiu, majac do dyspozycji minimalne środki materialne) прожить на что; za 1137 rubli / za stypendium w wysokości 25 rubli / za literacki zarobek / za jedną wypłatę / za zasiłek прожить на 1137 руб. / на стипендию в 25 рублей / на литературные заработки / на одну зарплату / на пенсию / на пособие

Pomimo że jest to model artykułu dla słownika przekładowego typu ogólnego, spełnione są w nim zarówno oczekiwania wobec leksykografii dydaktycznej, jak i ogólnej, które wybrzmiały w części teoretycznej niniejszego artykułu. Czytelnikowi pozostawiamy ocenę jego elegancji, jak to ujmuje Bańko. Model oczywiście nie jest zamknięty, a samą liczbę kolokantów (zgodnych z regułami łączliwości i potwierdzonych tekstowo), ich jakość czy formę podawczą można, a nawet należy dyskutować. 


\section{PODSUMOWANIE}

Reasumując, należy jeszcze raz zauważyć, że ogólny słownik przekładowy najczęściej nie jest jeszcze źródłem, posiadającym wyraźne walory akwizycyjne. Zauważalne jest jednak w metaleksykografii zacieranie się granic pomiędzy typami opisu słownikowego. Można więc z dużą dozą optymizmu zakładać, że przyszłe słowniki przekładowe będą słownikami, których autorzy $\mathrm{w}$ równiej mierze będą doceniać zgodność opisu języka ze sztuką leksykograficzną i wiedzą lingwistyczną (w tym przekładoznawczą), co tzw. elegancję, a więc połączenie dokładności ze zwięzłością i prostotą, uwzględniającą ludzką percepcję informacji. Być może, aby mogło się tak stać, metaleksykografia ogólna powinna więcej czerpać z dorobku glottodydaktyki, dydaktyki, psychologii czy kognitywistyki.

Bezsprzeczny jest natomiast fakt, że uczymy się języka poprzez przykłady. Odpowiednia ich selekcja, czytelna dyferencjacja i forma podawcza kolokacji w słowniku niewątpliwie zwiększą jego użyteczność. Leksykografowie mają obecnie do dyspozycji narzędzia umożliwiające relatywnie szybką i wiarygodną analizę oraz weryfikację nie tylko zjawisk językowych jako takich, ale również weryfikację rozwiązań zawartych w słownikach dotychczasowych (tak objaśniających, jak i wielojęzycznych). Te możliwości, których jeszcze kilka dziesięcioleci temu nie było, pozwalają sądzić, że zacieranie się granic pomiędzy typami słowników będzie postępować.

Jak ponad dekadę temu słusznie zauważył Piotr Żmigrodzki: „[odbiorcy] wymagają coraz wszechstronniejszej informacji zawartej w jednym miejscu (bądź w jednym urządzeniu)" (97). Oznacza to m.in. tyle, że twórcy słowników (co najmniej ogólnych) będą musieli jako zasadę prymarną przy układaniu słowników w coraz większym stopniu przyjmować szeroko pojmowaną perspektywę użytkownika.

\section{BIBLIOGRAFIA}

Atkins, Sue. „Bilingual dictionaries: Past, Present and Future”. Euralex '96 Proceedings I, red. Martin Gellerstam et al., Göteborg University, 1996, ss. 515-546.

Bańko, Mirosław. „Za mało czy dość? Dylemat leksykografa w dobie rewolucji informacyjnej (na przykładzie słowników frazeologicznych)". Perspektywy współczesnej frazeologii polskiej. Między teoria a praktyka frazeograficzna, red. Gabriela Dziamska-Lenart, Jarosław Liberek, Wydawnictwo Naukowe UAM, 2013, ss. 9-16.

Grochowski, Maciej. Zarys leksykologii i leksykografii. Zagadnienia synchroniczne. Uniwersytet Mikołaja Kopernika, 1982. 
Labocha, Maciej. „Myśl - słowo - użycie, czyli o strukturze semantycznej artykułu hasłowego w słowniku przekładowym polsko-rosyjskim na przykładzie polskiego leksemu przeżyc oraz jego rosyjskich odpowiedników”. Stowiański krąg. Stowo - myśl - obraz w tradycji $i$ współczesności, red. Aneta Banaszek-Szapowałowa, Wydawnictwo Naukowe Uniwersytetu Śląskiego, 2019, ss. 283-292.

Piegzik, Wioletta. „Intuicja w uczeniu się języka obcego”. Neofilolog. Czasopismo Polskiego Towarzystwa Neofilologicznego, nr 50 (1), 2018, ss. 143-157.

Piotrowski, Tadeusz. „Ekwiwalencja w słownikach dwujęzycznych”. Na tropach translatów. W poszukiwaniu odpowiedników przekładowych, red. Wojciech Chlebda, Wydawnictwo Uniwersytetu Opolskiego, 2011, ss. 45-69.

Przybylska, Renata, Piotr Żmigrodzki i Katarzyna Węgrzynek. „Zasady opisu związków frazeologicznych w Wielkim słowniku języka polskiego PAN'. Perspektywy wspótczesnej frazeologii polskiej. Między teoria a praktyka frazeograficzna, red. Gabriela DziamskaLenart i Jarosław Liberek, Wydawnictwo Naukowe UAM, 2013, ss. 17-27.

Rokicka, Teresa. „Status kolokacji w Wielkim słowniku języka polskiego”. Nowe studia leksykograficzne, red. Piotr Żmigrodzki i Renata Przybylska, Wydawnictwo Lexis, 2007, ss. 79-86.

Spitzer, Manfred. Jak uczy się mózg?. Wydawnictwo Naukowe PWN, 2012.

Targońska, Joanna. „Innowacje metodologiczne - zastosowanie innowacyjnych technik elicytacji w badaniu kompetencji kolokacyjnej". Neofilolog. Czasopismo Polskiego Towarzystwa Neofilologicznego, nr 50 (1), 2018, ss. 109-125.

Vlavatskaya, M.V. „«Users needs» kak trebovaniya k sostavleniyu anglo-russkogo uchebnogo kombinatornogo slovarya." Voprosy leksikografii, nr 2 (4), 2013, ss. 32-40. [Влавацкая, M.В. „«Users needs» как требования к составлению англо-русского учебного комбинаторного словаря.” Вопросы лексикографии, nr 2 (4), 2013, ss. 32-40.]

Żmigrodzki, Piotr. Słownik - słowo - rzeczywistość. Z problemów leksykografii i metaleksykografii. Wydawnictwo Lexis, 2008.

\section{ŹRÓDŁO MATERIAŁU EGZEMPLIFIKACYJNEGO}

Natsional'nyy korpus russkogo yazyka / Национальный корпус русского языка. ruscorpora.ru/ new/index.html.

\section{ŹRÓDEA LEKSYKOGRAFICZNE I SKRÓTY UŻYTE W TEKŚCIE}

Wielki stownik polsko-rosyjski [i] rosyjsko-polski, red. Sergiusz Chwatow i Mikołaj Timoszuk, Wydawnictwo REA, 2008. (WSPR[i]RP REA)

Wielki słownik polsko-rosyjski P-Ż, red. Dymitr Hessen i Ryszard Stypuła, Wyd. VII, Wydawnictwo Wiedza Powszechna, 2004. (WSPR WP)

Wielki stownik polsko-rosyjski i rosyjsko-polski 2.0, red. Jan Wawrzyńczyk, Wydawnictwo PWN, 2007 - edycja na płycie CD. (WSPRiRP PWN)

\section{GLOTTODYDAKTYCZNE ASPEKTY \\ OPISU SŁOWNIKOWEGO KOLOKACJI}

Streszczenie

Celem artykułu jest rozwinięcie problematyki semantycznej struktury artykułu hasłowego w słowniku przekładowym (dwujęzycznym) w kontekście glottodydaktycznym. Zasadniczym przedmiotem badań są kolokacje, stanowiące zarówno ilustrację dla jednostek hasłowych, jak 
i będące elementem dwustopniowej weryfikacji semantycznej i uzualnej dla użytkownika słownika. Odpowiednio dobrane zestawy połączeń wyrazowych przedstawiają wartość dydaktyczną i są postulowane zarówno przez badaczy przekładowych słowników dydaktycznych, jak i przekładowych słowników ogólnych. W związku z tym w artykule prezentowany jest model artykułu hasłowego spełniający oczekiwania zarówno leksykografii dydaktycznej, jak i ogólnej. Dobór poszczególnych kolokacji oparty jest na badaniu korpusowym (Narodowy Korpus Języka Rosyjskiego). Analiza zaproponowana w artykule pokazuje, że możliwe jest również ustalenie czytelnych schematów łączliwości, które mogą pomóc w poszukiwaniu optymalnego zestawienia kolokacji na potrzeby leksykograficzne.

Słowa kluczowe: leksykografia; artykuł hasłowy; kolokacje; słownik przekładowy; słownik dwujęzyczny.

\section{GLOTTODIDACTIC ASPECTS OF COLLOCATIONS IN DICTIONARY ENTRIES}

\section{Su m mary}

This article expands on the issues related to the structure of dictionary entries in bilingual dictionaries and to their glottodidactic context. It predominantly focusses on collocations which illustrate specific entries and serve as a dual-level semantic verification for dictionary users. Appropriately matched word sets can be a valuable resource in language didactics, as has been suggested by research investigating dictionaries both for learners and for general use. Thus, this article presents the model of a dictionary entry meeting the standards of both didactic and general lexicography. The selection of specific collocations is based on a corpus study (The National Corpus of the Russian Language). The analysis presented here reveals that it is possible to establish clear schemata of connectivity, which can help in searching for optimal collocation matches for lexicographical needs.

Keywords: lexicography; dictionary entry; collocations; translation dictionary; bilingual dictionary. 